\title{
The successor states of the Austro-Hungarian Empire in the Polish diplomacy (1918-1920)
}

\begin{abstract}
Summary. Austria, Hungary, Czechoslovakia, Romania, the Kingdom of SCS and Poland are the countries referred to as successor states of the Habsburg Monarchy since they were established out of its ruins. This article focuses on how meaningful these Central European states were to Polish diplomacy in 19181920 , i.e. the period which was decisive in the creation of their independent existence. The aim of the article is to answer the question of how the gradual breakup of the unitary Austria-Hungary in 1918 was perceived by the Polish political elites. It will also examine what stance the government of the independent Polish state adopted towards the new countries that were being formed after the dissolution of the Habsburg Monarchy. All the states which were fully or partially composed of the former Austro-Hungarian territories are considered with the exception of Italy which was already recognised as one of the most important European powers and after its annexation of the Habsburg lands on the Adriatic Sea was even more of a power. The article will also explore whether the emerging countries played any role in the development of Polish foreign policy and if so, how significant this role was. A similar question can be asked in the case of the entire territory of the Danube Region. After the First World War, its political and economic unity was shattered, which could have been used by the nascent Poland while dealing with its weaker partners.
\end{abstract}

Keywords: Polish diplomacy, Austro-Hungarian successor states, Danube Region.

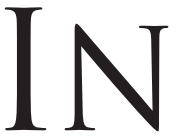

the existing literature, "successor states" are defined as the countries of the Central and Eastern Europe which were established out of the ruins of the Habsburg Mon-

* The Faculty of Philosophy and History, The Institute of History, The Department of Contemporary World History / Wydział Filozoficzno-Historyczny, Instytut Historii, Katedra Historii Powszechnej Najnowszej, e-mail: dariuszjeziorny@uni.lodz.pl. 
archy. Not everyone approves of this name. For example, Czechoslovakia did not want to be considered a "successor" of the Austro-Hungarian Empire. Nevertheless, the name seems to be a neat and short description of the so-called nation states, which is not a precise term in the case of Poland, Czechoslovakia, Hungary, Romania or the Kingdom of Serbs, Croats and Slovenes (further on: the Kingdom of SCS) either. It corresponds most precisely to the interwar Austria, which was a German-speaking remnant of the centuries-old monarchy.

As for the timeframe of the article it starts with the creation of the Polish state in November 1918 and the disintegration of the Austro-Hungarian Empire. The motivation behind the choice of the end date of 1920 may seem less clear, though there are several reasons for it. First of all, Poland finished its fights with the Bolsheviks and thus, could focus on other borders instead of only on the Western and Eastern ones. Secondly, Hungary signed and ratified the Treaty of Trianon, which put an end to the uncertainty as to what the country of the Crown of Saint Stephen and its borders would look like. The policy of France towards the Danube Region was also clarified - there was no doubt that Paris would support the new states which started forming the Little Entente in June 1920 against Hungary. In Austria, the first period of republican rule was coming to an end and after the October parliamentary elections, the Social Democrats lost its power in Vienna. As it turned out later, they did not manage to retake it in the interwar period.

The aim of the article is to answer the question of how the Polish political elites responded to the breakup of Austria-Hungary in 1918 and what stance was adopted by successive Polish governments towards the states which were subsequently established out of the ruins of the dual monarchy. All the countries that claimed sovereignty over a bigger part of the Austro-Hungarian territory, namely Austria, Czechoslovakia, Hungary, Romania and the Kingdom of SCS, will be included in the discussion. What is more, the author will examine whether all these countries had any significant influence on the development of Polish foreign policy and if so to what extent. A similar question can be asked in the case of the entire territory of the Danube Basin.

During the battles of World War I which broke out in 1914, the matter of the dissolution of Austria-Hungary was observed within Polish political circles in the spring of 1918. The Polish National 
Committee was first to address the issue in April 1918 at the Congress of Opressed Nationalities organized in Rome by the Entente governments. Roman Dmowski and a group of his co-workers sympathised with the resolutions adopted at the meeting in the Italian capital, which were aimed at weakening the relations between the nations that were until now mainly subject to German and Hungarian domination. In fact, the Polish delegates prepared these resolutions with the French, along with representatives of the Czechs, Slovaks, South Slavs and Romanians ${ }^{1}$. Another opportunity to manifest their collective negative attitude towards the Habsburg monarchy was seized when the Entente governments, with Polish support, recognized the independence of Czechoslovakia. The Czechoslovak National Council operating in the West was to be recognized as a representative of the Czechs and Slovaks as well as to have authority over the 50,000 strong Czechoslovak Corps which, at the time was present in Siberia. This would mean that Prague would be unequivocally freed from dependency on Vienna as would Galicia due solely to its geographical situation ${ }^{2}$. The peace note from the Central Powers, which was announced on October 4, 1918, became a third opportunity to support separatist aspirations within the Austro-Hungarian Empire. In the note, Minister István Burián appealed to the US President Thomas Woodrow Wilson to start peace negotiations on the territory of a neutral country $^{3}$. The Austro-Hungarian authorities were promising to transform the dual monarchy approach to ruling the area into a federal system. The Polish National Committee stigmatized this as a false promise and together with representatives of the three other opressed nationalities inhabiting the Habsburg monarchy protested against "the act of diplomatic hypocrisy" - as Burián's move was described, and advocated complete Polish independence.

1 O niepodległa i granice. Komitet Narodowy Polski. Protokoły posiedzeń 19171919, eds M. Jabłonowski, D. Cisowska-Hydzik, Warszawa-Pułtusk 2007, pp. 216, 286, protocols from sittings of the Polish National Committee from Dec 14, 1917 and Feb 28, 1918 (annex 4).

2 D. Perman, The Shaping of Czechoslovak State. Diplomatic History of the Boundaries of Czechoslovakia, 1914-1920, Leiden 1962, pp. 37-44; H. Par a fianow icz, Czechosłowacja w polityce Stanów Zjednoczonych w latach 1918-1933, Białystok 1996, pp. 50-57.

${ }^{3}$ W. F e st, Peace or Partition. The Hapsburg Monarchy and British Policy. 1914 1918, London 1978, pp. 251-252. The contents of this note was already included in Burián's speech from Sep 10, which was published in the Krakow daily "Czas" on Sep 11 (the morning ed.) 1918, p. 1. 
At the same time, the Committee expressed its confidence in "the Entente nations' sense of justice", which would ultimately lead to their "liberating victory", once "the weaknesses of the Central Powers are revealed"4.

The Regency Council operating in Warsaw, quite unlike the Polish National Committee, could not afford such far-reaching honesty since it maintained official relations with Vienna. However, on October 7, 1918, the Regency Council proclaimed the independence of Poland, declaring that this country should consist of the territories inhabited by Poles. It was undoubtedly a measure against Austria-Hungary as it equivocally implied that the Empire would no longer exercise its sovereignty over Galicia. All the same, it did not mean that the Regency Council had radically changed its policy and broken its relations with Vienna. The sole fact that the Danube monarchy was notified that the government of Józef Swieżyński was set up on October $23^{5}$ demonstrated great caution by the politicians in Warsaw.

The last important political circle of influence at that time was connected with Józef Piłsudski. Yet, he himself did not have an opportunity to take a stance on or influence the dissolution of Austria-Hungary since throughout the dissolution process - which turned out not to last that long - he was still in prison. He returned to Warsaw on November 11 , when the Habsburg monarchy already no longer existed. His resignation from the post of a commander of Legions on 26 September 1916 meant a break with the occupants of the Kingdom of Poland and with the Austro-Hungarian Empire in particular. Although Piłsudski supported the Act of 5 November because it permitted him to concentrate on the military aspect of his contacts with the Central Powers, he was fully aware that Vienna was less and less meaningful in solving the Polish question. Subsequent events led to the oath crisis, which resulted in his imprisonment. Thus, it was not difficult to observe the evolution of his stance that ended in abandoning the hopes which he had vested in Vienna ${ }^{6}$.

${ }^{4}$ O niepodległa i granice..., pp. 576-577, a draft declaration of the four committees of the oppressed nationalities of Austria-Hungary, Paris Oct 10, 1918.

5 J. Pajewski, Odbudowa państwa polskiego 1914-1918, Warszawa 1985, pp. 272, 278-280.

${ }^{6}$ J. Lewandowski, Królestwo Polskie wobec Austro-Wegier 1914-1918, Warszawa-Łódź 1986, pp. 105, 116-118; R. Świętek, Lodowa ściana. Sekrety polityki Józefa Piłsudskiego, 1904-1918, Kraków 1998, pp. 813-814, 818-820. 
How the Polish government perceived the effect on their own political position of the roles and actions of each successor state will be assessed separately on a country by country basis. Firstly, the Republican Austria is worthy of attention. It did not have a common border with Poland and yet, Warsaw was certainly very interested in it. Polish representatives reported regularly on a dramatic social situation including revolutionary tendencies among the population, riots caused by hunger in the major cities, demonstrations of the unemployed and the homeless, anarchy and organizational chaos. All this was accompanied by a total collapse of public finances. Unable to balance current public expenditure, the authorities had to resort to printing worthless banknotes. It resulted in a rapid drop in the value of the Austria-Hungarian crown and foreshadowed the bankruptcy of the republican country. The territory of Austria was made up of what remained after its neighbours reclaimed their land in territorial disputes and settlements. Balancing the budget with tax revenues was out of the question since once the Austrian territory was limited to the lands inhabited only by the German speaking population around Vienna and in the provinces of the Alps, the country was made up of 6-6.5 million people, with 2 million in the capital itself. In the budget estimate for 1919, the deficit was forecasted to reach 2.5 billion crowns, while the last deficit of the whole monarchy amounted to a mere 1.89 billion. In the middle of 1919 , the deficit was estimated at 8 billion, and a year later it increased to 20-26 billion crowns. The drastic and, at the same time, desperate measures taken by the Ministry of Finance, which were intended to generate income for the state, could not work miracles and keep the country solvent. The debt inherited from the Austro-Hungarian Empire was massive after the war and Vienna was burdened with it since the other successor states refused to participate in paying it back. In addition to the bankruptcy of the state budget, there was lack of both food and heating coal, especially in big cities. Both commodities were considered luxury goods. This shortage was not a new phenomenon - the population had been struggling with it all throughout the wartime year of 1918. Such a hopeless domestic situation within Austria gave rise to political tensions which added to the dispute concerning what to do for the future of the country. Two options were being considered: either the Anschluss to Germany backed by Socialdemocrats and Pan-Germans, or the renewal of ties with the nations which were thus far co-creating 
the Habsburg monarchy. The Christian Social Party claimed the latter course more and more boldly. Being aware of the economic failure of the country, no one promoted the idea of the independent Austria. Yet, for obvious reasons, the supporters of each of the two mentioned concepts could not be reconciled ${ }^{7}$.

Warsaw's attitude was lukewarm towards both of the proposed options. The Anschluss would strengthen Germany, and it was already threatening Polish independence and territorial sovereignty and was also seeking to recover territorial losses incurred after the First World War. Moreover, railway transports from France to Poland without transiting Germany would be enabled if the Republican Austria remained independent and thus Poland would be able to make a railway connection with France though Austria, Czechoslovakia and Switzerland, thus avoiding German territory. For strategic reasons such a railway connection was an important condition for the security of Poland. On December 31, 1919, representatives of the Polish and Austrian governments signed a detailed agreement on the France-Poland rail transit that would run through Austria. Nonetheless, when the Bolsheviks were approaching Warsaw in the summer of 1920, the rail transit agreement proved to be useless once the Czechoslovak government announced neutrality. Moreover, Prague convinced Austria to make a similar declaration of neutrality. Thus, as of August 9, 1920, the hoped for rail link around Germany which would enable future strategic aid to be delivered to Poland became unrealistic ${ }^{8}$.

7 D. J eziorny, Austria kanclerza Karla Rennera (1918-1920) w raportach polskich dyplomatów $i$ wojskowych, [in:] Austria i relacje polsko-austriackie w XX i XXI wieku. Polityka - kultura - gospodarka, eds A. Kisztelińska-Węgrzyńska, K.A. Kuczyński, Łódź, 2014, pp. 69-71; report by E. Parnes (the head of the Press Office of the Polish mission to Vienna) from Feb 11, 1919, The Central Archives of Modern Records in Warsaw [further on: AAN], The Polish National Committee [further on: KNP], file 50, sheet No. 64-69, 72-73; report for the High Command of the Polish Army [further on: PA] from Dec 1, 1920, AAN, The Ministry of Foreign Affairs [further on: MSZ], file 215, sheet No. 40-41. Gustav Stolper (Deutsch-Österreich als Sozial- und Wirtschaftsproblem, Wien 1921, p. 34) maintains that the deficit in the first half of the 1919 amounted to 10 billion crowns, which is more than stated by the Polish diplomats.

${ }^{8}$ E. Piltz (a representative of KNP to the government of France) to the French MFA, Paris Dec 27, 1918, Polskie dokumenty dyplomatyczne 1918: listopadgrudzień [further on: PDD 1918], ed. S. Dębski, Warszawa 2008, pp. 369-370; J. Leśniewski (lieutenant-general, Minister of Military Affairs in the government of I. Paderewski) to Paderewski (Prime Minister of Poland), Warszawa Apr 1, Archi- 
A less significant aspect, but nonetheless an influence on Polish diplomatic thinking in relation to Austria was the issue of relocating the government of the Western Ukrainian People's Republic (further on: WUPR) to Vienna. The Ukrainian authorities remained decidedly hostile towards Warsaw after defeats in Eastern Galicia. At the beginning of November the Poles were spreading rumours in Western European countries that the Austrian officers set the Ukrainians against Poles and it resulted in bloody Polish-Ukrainian battles for Lviv. Since Vienna did not react to the actions of the exiled WUPR government, the military operations of the Polish army could be justified as a part of the Entente camp's struggle with the enemies belonging to the Central Powers 9 .

Due to all above-mentioned factors, Poland did not perceive Vienna as a possible political partner. At best, it could become an importer of Polish coal, the shortage of which the Danube region was definitely facing. The Czechs, however, blocked the deliveries from Poland, hoping to exert pressure on Austria. Given the prevailing political climate during the discussions concerning the dissolution of the dual monarchy there was nothing left for Warsaw to do but to negotiate the greatest possible deal in terms of the distribution of material goods and money as did the other successor states that were involved ${ }^{10}$. Therefore Austria did not have

wum Polityczne Ignacego Paderewskiego [further on: APIP], vol. II, ed. W. Stankiewicz, Warszawa 1976, p. 76; a text of the agreement of Dec 31, 1919, AAN, Attachaty [The Defense Attache Offices], AII/56, sheet No. 304-312; A. Essen, Polityka Czechosłowacji w Europie Środkowej w latach 1918-1932, Kraków 2006, pp. 45-47; S.M. Nowin ow ski, Konstatacje i nadzieje. Dyplomacja czechosłowacka wobec kwestii bezpieczeństwa zbiorowego w Europie (1918-1925), Toruń 2005, pp. 80-85.

9 A draft note of KNP, Nov 13, a note of the Polish MFA from Nov 22, a letter from Lviv to KNP from Dec 25, 1918, PDD 1918, pp. 9-11, 66, 353-354; K. Gałecki (the Polish representative in Vienna until the end of March 1919) to Paderewski, Vienna Feb 8, 1919, APIP, vol. V, ed. B. Janicka, Warszawa 2001, p. 28; reports for the High Command of PA, Aug 15 and Sep 1, AAN, MSZ, file 215, sheet No. 11, 22-24; Szarota to the MFA, Vienna Sep 1920, APIP, vol. VI, eds A.G. Dabrowski et al., Warszawa 2007, pp. 219-221.

${ }_{10}$ M. Zamoyski (Polish envoy in Paris) to the MFA, Paris Dec 12, 1919, AAN, The Polish Embassy in Paris [further on: Amb. Paryż], file 36, sheet No. 112-114. Preparing for the negotiations, the Polish delegation intended to: calculate what loss the Polish population sustained on the use of the Austrian currency; distribute assets and reserves of insurance funds for workers, pensioners and disabled war veterans; estimate the value of the Austrian national railway within the territory that was assigned to Poland in order to split the shares; bring about a division 
significant importance from the perspective of Warsaw. However, Adam Nowotny and Marceli Szarota (the Polish military representative and the Polish charge d'affaires in Vienna, respectively) saw Austria as an important source of political rivalry for those powers that were hoping to embrace it into their sphere of influence, in political and economic terms (using railways, taking advantage of hydropower of Austrian rivers etc.). This was particularly true in the case of France and Italy ${ }^{11}$, but a total exaggeration in the matter of Anglo-Saxon powers ${ }^{12}$.

The country that was far more interesting to Warsaw was Czechoslovakia - the immediate neighbour from the south. Poland perceived it as a weak and internally unstable structure because of its numerous minority groups. Despite the seemingly prevailing democratic system Polish observers noticed a progressive centralisation of power in Czechoslovakia and a domination of five Czech parties, forming the majority of the Czechoslovak cabinets of the interwar period (the so-called "petka" system, i.e. rules of five). Poland was aware that this "petka" seemed the only political alternative likely to avoid the disintegration of the neighbouring country but nonetheless the whole of the First Republic seemed to be com-

of military estate, factories of ammunition, the supply of weapons and ammunition, which could have been of immense significance as the situation on all the borders was unstable; get shares in the reserves of the Austro-Hungarian Bank and postal savings banks; calculate direct and indirect war losses in order to get compensation for them in gold currency or in articles; bring about the recovery of cultural heritage as well as to share debts of Austria-Hungary that would be most beneficial to Warsaw - see A list of expert opinions commissioned by the Bureau of Congress Works in connection with the Peace Conference, before Dec 27, 1918, PDD 1918, pp. 179-180.

${ }^{11}$ Nowotny to the Ministry of Military Affairs, Vienna, May 7 and reports from Vienna from May 21, AAN, KNP, file 50, sheet No. 79-82; M. Loret (a member of KNP mission in Rome and since Feb 14, 1919, a representative of the Polish government) to the MFA, Rome March 28, ibidem, file 104, sheet No. 73-74; Zamoyski to the MFA, Paris Dec 15, AAN, Amb. Paryż, file 36, sheet No. 116; an annex to Zamoyski's report from Dec 19, 1919 (the same document in AAN, MSZ, file 3674, sheet No. 1-7, dated Dec 20, 1919), ibidem, file 11, sheet No. 30-37; Szarota's reports, Jan and May 28, ibidem, file 223, sheet No. 1-2, 4-6; AAN, The Polish Embassy in Berlin [further on: Amb. Berlin], file 26, sheet No. 21 V; Szarota to the MFA, Vienna Jan 23, AAN, The Polish Embassy in London [further on: Amb. Londyn], file 5, sheet No. 56-57; political review, No. 23 from Jun 28, 1920, AAN, The Polish Legation in Athens, file 415, sheet No. 33.

12 D. J eziorny, German Austria - British Colony? An Episode of the British Policy towards Central Europe in 1919, [in:] The Role of Britain in the Modern World, eds K. Kujawińska-Courtney, R. Machnikowski, Łódź 1999, pp. 177-193. 
ing apart at the seams. There were strong emancipatory trends among Slovaks (according to Alfred Wysocki, the Polish chargé d'affaires in Prague, the movement was too weak to threaten the unity of Czechoslovakia) who did not like the Czech domination. The Hungarians were harbouring revisionist claims concerning the Transcarpathian Ruthenia and the southern part of Slovakia, and even the whole land which historically belonged to the Crown of St Stephen. There were in addition strong separatist movements within the Germans living in the Province of German Bohemia, the Sudetenland, southern Moravia and southern Bohemia - the whole of the First Republic was a boiling pot ${ }^{13}$.

Warsaw was pleased to watch the inner tensions of its southern neighbour since Czechoslovakia was another unfriendly country with which the rebuilding Polish state had conflicts. Both states competed to be in the lead role of being the Entente's main partner in East Central Europe. However, in the initial stage of rebuilding of the two statehoods, it seemed that Prague was gaining advantage in the race, enjoying greater popularity in the Western European capitals and having much less dangerous opponents at its borders. This view was confirmed by Erazm Piltz, who was a member of the Polish National Committee in Paris ${ }^{14}$.

13 The inspector of Border Police (signature illegible) to the German Ministry of Internal Affairs, Frankfurt an der Oder Dec 6, 1919, AAN, Amb. Berlin, file 49, sheet No. 1-2; P. W andycz, Erazm Piltz a koncepcja polityki środkowoeuropejskiej, [in:] Międzymorze. Polska i kraje Europy Środkowo-Wschodniej XIX-XX wiek. Studia ofiarowane Piotrowi Łossowskiemu $w$ siedemdziesiąta rocznice urodzin, eds A. Ajnenkiel, P. Łossowski, Warszawa 1995, p. 220; excerpts from the reports on the situation in Bohemia from Jun 17 and Jul 6, AAN, Amb. Londyn, file 55, sheet No. 22ab, 30-31; excerpts from the report of the Polish Legation in Bern from Oct 7, ibidem, file 87, sheet No. 10-12; report for the High Command of PA from Dec 1, AAN, MSZ, file 217, sheet No. 132-134; L. Malczewski (secretary of the Polish Legation in Czechoslovakia) to the MFA, Prague Dec 15, ibidem, file 5439, sheet No. 42-55; Malczewski to the MFA, Prague, Nov 20 and Wysocki to the MFA, Prague Oct 28, 1920, ibidem, file 5442, pp. 26-35. See A. Szk1arska-Lohmannowa, Polsko-czechosłowackie stosunki dyplomatyczne $w$ latach 1918-1925, Wrocław 1967, pp. 19-36, 121-124; P. M aje w s ki, "Niemcy Sudeccy" 1848-1948. Historia pewnego nacjonalizmu, Warszawa 2007, 162-176, 188-192; D.E. Mille r, Forging Political Compromise: Antonin Švehla and the Czechoslovak Republican Party. 1918-1933, Pittsburgh 1999, chap. II.

14 S.M. Now inowski, Stosunki polsko-czechosłowackie u progu drugiej wojny światowej. Bilans otwarcia, [in:] Między przymusowa przyjaźnia a prawdziwa solidarnościa. Czesi-Polacy - Słowacy 1938/39-1945-1989, part 1, eds P. Blažek, P. Jaworski, Ł. Kamiński, Warszawa 2007, p. 13; D. J e zi o r ny, Raporty znad Wełtawy - narodziny Czechosłowacji widziane oczami Cecila Goslinga, [in:] Cze- 
Apart from the disputes over the leading role in the region, there were also border conflicts between Poland and Czechoslovakia. Most of all, it was about the affiliation of Cieszyn Silesia and the mines located in the area. The Poles argued that they constituted the largest national group within the disputed territory of Karvina and Petrvald but they failed to produce a desired outcome by peaceful means. The Czechs took advantage of the Polish weakness and their preoccupation with conflicts on their eastern borders along with the pressure of Germany which persisted even since the peace agreement. Feeling therefore that they would run no risk of retaliation Czechoslovakia captured a considerable part of the disputed lands, together with Zaolzie ${ }^{15}$.

In order to weaken Poland even more, Prague supported the Western Ukrainian People's Republic in their armed conflict with the Poles. The Ukrainians in the Transcarpathian Ruthenia had been granted autonomy by the Czechs with the aim of preventing the Polish troops from seizing Eastern Galicia. A side effect of depriving Warsaw of this territory was that it also offered Czechoslovakia the opportunity of having a common border with Ukraine, or rather with Russia, and serving as a bridge between the East and the West ${ }^{16}$.

For the same reason the Czechs were willing to establish contacts with the Belarusians and the Lithuanians. The possible link between the Czechs and Lithuanians was especially unwelcome in Warsaw. The Polish conflict with Lithuania would not only mean gaining another hostile neighbour, but also the failure of the fed-

chosłowacja $w$ stosunkach międzynarodowych $w$ pierwszej połowie XX $w$. Studia $i$ szkice, ed. A.M. Brzeziński, Warszawa 2003, pp. 8-22; P. W andycz, op. cit., p. 219.

${ }^{15}$ Demographic statistics from June, AAN, The Polish Delegation to the Paris Peace Conference, file 45, sheet No. 1-3, 6; instruction for the heads of Polish diplomatic missions from Jul 7, 1919, APIP, vol. II, pp. 254-255; A. Es s e n, Polska a Mała Ententa 1920-1934, Warszawa-Kraków 1992, p. 25; A. Szklarska-Lohmannowa, op. cit., chap. II. Most extensively on the topic: M.K. Kamińs ki, Konflikt polsko-czeski 1918-1921, Warszawa 2001.

${ }_{16}$ Report for the High Command of PA from Sep 1, AAN, MSZ, file 215, sheet No. 22-24; report for the High Command of PA from Nov 15 1920, ibidem, file 217, sheet No. 155. For more: K. Lew a nd ow ski, Sprawa ukrainska w polityce zagranicznej Czechosłowacji w latach 1918-1932, Wrocław 1974, chap. II-III; P. W a nd y cz, France and her Eastern Allies 1919-1925. French-Czechoslovak-Polish Relations from the Paris Peace Conference, Minneapolis 1962, pp. 107-111; A. Es s en, op. cit., pp. 16-18. 
eral concept, the intention of which was to avert the dangers arising from the proximity of Russia - no matter "white" or "red" 17 .

Another issue worth mentioning is the propaganda against Poland which originated in Czechoslovakia. The National Socialist (not to be confused with German Nazis!) played the leading role in this respect. They tried to give the widest publicity to their claims about such things as the chaos in Poland that could lead to the outbreak of Bolshevism; selfish Polish "imperialism"; the chauvinist intolerance of the Polish people towards other nationalities; the obsolete social model, in which the backward nobility played a dominant role; the excessive influence of the Roman Catholic Church, etc. ${ }^{18}$ All of that was done to spread a repugnant image of Poland, both in Czechoslovakia and in the rest of Europe.

The government of Poland watched the gradual arming of the southern neighbour with great concern. It involved the re-distribution of supplies from Austrian arsenals and factories (mainly Wiener Neustadt). By threatening to cut off the deliveries of coal and being able to put pressure on Austria, Prague successfully managed to obtain war materials, making sure they would not get into hands of other countries that needed them, including Poland ${ }^{19}$.

Another point of disagreement was the Czech policy of neutrality. It was adopted in the unfavourable and dramatic times when the Poles were trying to rebuild their state and the Bolsheviks were approaching Warsaw. Prague declared neutrality on August 9, 1920, and then persuaded the Austrian government to do the same. As a result, possible deliveries of warlike materials from France to Poland on a railway route which would bypass Germany was cut off. The Germans could not contain their satisfaction with the

17 P. Wandycz, Erazm Piltz..., p. 221.

18 S.M. Nowi now ski, Polska w dyplomacji czechosłowackiej 1926-1932, Łódź 2013, pp. 10-17. See examples of spreading hostile propaganda against the Polish in the Western countries: Foreign Office Political Intelligence Department, report on Slavic issues, Apr 1 (here, on the anti-Jewish activities of the Poles), The National Archives, London, Foreign Office 371/4373/589, 600; comments of Lewis B. Namier (an officer of the Political Intelligence Department) from Jan 20, 1919, ibidem 371/3896, No. 5255. See the Polish perception of the Czech action in K. Świtalski, Diariusz 1919-1935, eds A. Garlicki, R. Świętek, Warszawa 1992, p. 65, entry from Nov 4, 1920.

19 Note of the General Staff from Mar 24, 1919, AAN, KNP, file 104, sheet No. 91; reports for the High Command of PA from May 1 and Aug 15, AAN, MSZ, file 217, sheet No. 2, 47; an excerpt from the report of the Polish Legation, Vienna Sep 23, 1920, AAN, Amb. London, file 11, sheet No. 79. 
decision to stop all the rail shipments to Poland ${ }^{20}$. The ability of Poland to repel any future invasion was reduced.

Poland and Czechoslovakia also differed significantly in their thinking for one strategical reason. In the spring of 1920, Eduard Beneš, Czechoslovak Minister of Foreign Affairs, made efforts to build an alliance with the Kingdom of SCS. It could strengthen both countries facing possible Hungarian revisionism, but also lead to a takeover of Western Hungary, called Burgenland by the Germans. Sharing this territory between Czechoslovakia and the Kingdom of SCS would establish a common border, and consequently, improve direct communication between the two Slavic countries. Another enormous advantage of this solution could be a permanent separation of Austria and Hungary so that these two dominant Habsburg lands would not be able to rebuild a dual state. Prague perceived such a possibility as a huge threat. Although the Polish view did not attach much weight to Beneš' efforts there was a deep understanding in Warsaw that any weakening of Hungary would be attractive to Bucharest. Any prospect of Romania joining the anti-Hungarian bloc seemed dangerous from the perspective of Warsaw. Poland feared that a close relationship between Bucharest and Prague could have a negative impact on Polish-Romanian cooperation against Russia, which to Polish thinking seemed to be an essential element for the future balance of power in Eastern Europe. For this reason, Warsaw tried to make it as difficult as possible for Beneš to cooperate with the Romanian liberals and conservatives, who were competing for power in Bucharest. Polish diplomacy wanted to avoid the situation in which any anti-Hungarian cooperation between Romania and Czechoslovakia would make the defensive Polish-Romanian alliance against the Russian threat impossible ${ }^{21}$.

${ }^{20}$ D. Jeziorny, Międzynarodowe znaczenie Austrii $w$ okresie rzadów Karla Rennera w ocenach dyplomacji polskiej, "Przegląd Zachodni" 2014, vol. LXX, No. 2, p. 141.

${ }^{21}$ Report for the High Command of PA from Dec 8, 1919, AAN, MSZ, file 6896, sheet No. 35; memorandum of the Director of the MFA Diplomatic Department from Aug 20, AAN, Amb. Paryż, file 9, sheet No. 20; report for the High Command of PA from Sep 1, 1920, AAN, MSZ, file 215, sheet No. 19-22; E. de W e is s, Dispute for Burgenland in 1919, "Journal of Central European Affairs" 1943, vol. III, No. 2, pp. 150-165; W. S tę p niak, Dyplomacja polska na Bałkanach (1918-1926), Warszawa 1998, pp. 74-75; H. Bułhak, Poczatki sojuszu polsko-rumuńskiego i przebieg rokowań o konwencje wojskowa w latach 1919-1921, "Dzieje Najnowsze” 1973, vol. V, issue 3, p. 22-23. 
Due to its having antagonistic relations with Prague Warsaw was virtually guaranteed to be favourably inclined towards almost any other country which came into a serious conflict with Czechoslovakia. Nevertheless, Polish-Hungarian cooperation was neither easy nor obvious and this was mainly due to the turbulent events that were taking place within Hungary. Shortly after the breakup of the Habsburg monarchy, Bela Kun assumed power in Budapest on March 23, 1919 and in his first statement he declared an alliance with Soviet Russia. It created an impression in Poland of being surrounded and "flooded with Bolshevism on all sides". Bela Kun hoped that the revolutionary wave that was approaching from the East would sweep away and engulf Romania which was hostile towards Hungary. Unfortunately for Kun, the advancement of Bolsheviks to the west was stopped in the spring of 1919 - it also met with an effective Polish counteroffensive on the Eastern Front. It meant a defeat for the ambitions of the communist regime in Budapest, but at the same time it laid the foundations of PolishHungarian cooperation. Poland closely monitored the Hungarian border conflicts and was fully aware of what actions the Hungarians took to improve their situation. They established cooperation with the Croatian federalists of Ivan Franko, but also with the Italians in order to weaken or even break up the emerging Kingdom of SCS. It became clear for the Poles that the political goals of the Croats and Italians were incompatible. In order to break up Czechoslovakia, the Hungarians also maintained contacts with the Slovak Ludaks led by Father Andrej Hlinka, with whom Poles also sought cooperation. The weakening of Czechoslovakia was the intention of both Budapest and Warsaw. Despite the radical anti-Bolshevik rhetoric spread in both countries in 1920, the Polish military men did not even try to conceal the fact that the motivation behind such rhetoric was not action against Russia but against Czechoslovakia ${ }^{22}$.

Polish diplomats also obtained information about the cooperation between the Hungarian government and the Austrian Christian Social Party, which at the time remained in opposition to the

${ }^{22}$ W. Wróblewski (Deputy Minister of Foreign Affairs) to the KNP, Warsaw Feb 25, 1919, and the report of Jerzy Potocki (the Polish military attaché in Budapest), Polskie dokumenty dyplomatyczne 1919: styczen-maj [further on: PDD 1919: styczeń-maj], ed. S. Dębski, Warszawa 2016, pp. 357, 564-565; excerpts from reports of the Polish Legation in Belgrade from May 6 and 8, 1920, AAN, Amb. Londyn, file 66, sheet No. 15, 18. 
government of Karl Renner. The Chancellor wanted to win at least one territorial conflict for the post-war borders and there seemed to be only one chance for it: seizing Burgenland, which since 1647 was a part of Transleithania. This led to conflict with Budapest and co-operation with Prague whose aim was to isolate Hungary, and even with Bucharest. In 1920, the tension between Austria and Hungary was so great that Polish diplomats did not rule out the possibility of war, especially because some border incidents were taking place, such as a Hungarian assault on an Austrian arsenal in Fürstenfeld. Both sides, however, avoided any major confrontation as it was not their real goal. The Poles monitored this dispute carefully, but were not directly interested in it. After the defeat of the Austrian Social Democrats in the elections of October 19, 1920, the new government of Michael Mayr quickly improved relations with Austria's western neighbour, but with no intention of giving up on the disputed territory. The fate of Burgenland was ultimately decided in Hungary's partial favour by the plebiscite in the Sopron comitat on Dec 14-16, $1921^{23}$.

From the Polish perspective, the conflict between Hungary and Romania was the worst factor of the East Central European situation. Romanian support had great potential value to the Poles. Hence, the Polish government pursued the formalisation of bilateral alliance and was ready temporarily to sacrifice the disputed area of Pokuttya ${ }^{24}$ in order to maintain military cooperation with Bucharest against Soviet Russia and the Western Ukrainian People's Republic. The development of the Romanian-Hungarian dispute over the lands of Transylvania, Maramureș and Banat was carefully observed by Polish diplomats. They even considered trying to mediate in the conflict in order to settle it and convince the two neighbours to collaborate against their common enemies. Even a personal union between the two countries was being considered

${ }^{23}$ D. Jeziorny, Miedzynarodowe znaczenie..., pp. 154-155; Szarota to the MFA, Vienna Jan 23 and Sep 25, AAN, Amb. Londyn, file 5, sheet No. 56-62; MFA to E. Sapieha (since June 16, 1919 a Polish envoy in London, and since Jun 23, 1920, the head of the MFA), Warsaw Mar 7 and 12, ibidem, file 11, sheet No. 75-78; report for the High Command of PA from Oct 15, 1920, AAN, MSZ, file 228, sheet No. 21; T. Spira, The Sopron (Ödenburg) Plebiscite of December 1921 and the German Nationality Problem, [in:] War and Society in East Central Europe, vol. VI (Essays on World War I: Total War and Peacemaking. A Case Study on Trianon), eds B.K. Király, P. Pastor, I. Sanders, New York 1982, p. 322.

${ }^{24}$ W. Stępniak, op. cit., pp. 48-50, 54-55, 78-80. 
in Warsaw. The desire to solve the Hungarian-Romanian issues by relieving the tension between them was increased by the prospect of good Budapest's relations with the British and French. Maurice Paléologue was a supporter of Hungary but he lost his position of the Secretary-General at the Quai d'Orsay in the summer of 1920. Till then it still seemed that all Warsaw's desires could be achieved. But finally the idea of mediation appeared to be a dream which could not be materialised owing to the intensity of the RomanianHungarian conflict and also because such a policy did not receive unambiguous support among the Polish diplomats. Jan Szembek (an envoy to Budapest) and Marceli Szarota were the main advocates, whereas group of diplomats rendered it impossible for Warsaw to go hand-in-hand with Hungary - which had been defeated in the World War I and to go against Czechoslovakia which was a protégé of France, Poland's most important ally. The impossibility factor was expressed by Erazm Piltz and Zygmunt Stefański (the Polish envoy and the chargé d'affaires in Belgrade, respectively ${ }^{25}$. Moreover, Italy did not approve of creating any block north of its borders that would prevent its own expansion and its increase of political and economic influence in Central Europe. Hence, the idea of Hungary cooperating with Poland and Romania - who were clearly inclined towards France - was unacceptable to Rome ${ }^{26}$.

In the end, Warsaw did not manage to ease the conflicts between Bucharest and Budapest and it resulted in the Romanian-Czechoslovak rapprochement. In the following months, the activity of Poland came down to monitoring the domestic situation in Romania, which was far from stable. Already weakened by the war, the country was additionally troubled with: domestic conflicts between rival conservatives and liberals, problems with national minorities

${ }^{25}$ Zamoyski to the MFA, Paris, Dec 19, 1919, AAN, Amb. Paryż, file 11, sheet No. 30, an excerpt from report of the Polish Legation in Budapest, Budapest Aug 7; AAN, Amb. Londyn, file 41, sheet No. 5-8; Piltz to Sapieha, Paris after Aug 6, APIP, vol. II, pp. 452-453; reports for the High Command of PA from May 1 and Oct 15, AAN, MSZ, file 224, sheet No. 4, 12; reports for the High Command of PA from May 1 and Dec 1, 1920, ibidem, file 228, sheet No. 9-10, 18-19; P. W andycz, Erazm Piltz..., pp. 220-224; J. Łaptos, Kształtowanie sie francuskiej koncepcji konfederacji naddunajskiej w latach 1918-1920, "Zeszyty Naukowe Uniwersytetu Jagiellońskiego. Prace Historyczne” 1991, issue 97, pp. 68-71.

${ }^{26}$ D. Jeziorny, Londyn a spuścizna po monarchii Habsburgów. Sprawa Austrii w koncepcjach i praktyce dyplomatycznej Wielkiej Brytanii (1918-1919), Torun 2002, p. 165; S. Sierpowski, Stosunki polsko-włoskie w latach 19181940, Warszawa 1975, pp. 215-216. 
- Jews in particular, and not least by the issue of integration of territories which were annexed after the First World War and which doubled the country's territory ${ }^{27}$. The foreign policy of Bucharest was not clear at all, i.e Romanians postponed concluding the alliance pact with Poland until the peace treaty was signed between Poland and Soviet Russia. Political and military cooperation was not the only question important to the government in Warsaw. For strategic reasons, it was important to facilitate the transit of possible aid to Poland through Romanian territory. After traumatic experiences of the Polish-Bolshevik war, the Polish military staff had no illusions that in case of military danger, the transports of material assistance from France would not be allowed to go through the territories of Switzerland, Austria and Czechoslovakia. And so, they tried to come up with other rail transit connections leading to Poland, one from Trieste and one from Brăila on the Danube. The first connection posed exactly the same obstacles as the route though Switzerland as it went through Austria and Czechoslovakia ${ }^{28}$, whereas the second one would lead through Romania which had much friendlier attitudes towards Poland. The downside of connection from Romania, however, was the lack of a decent, doubletrack railway line running from the port towards the border with Poland $^{29}$. Nevertheless, strategic interests encouraged Warsaw to conclude a military alliance and a common border with Romania, with which Poland was connected because of "extremely important interests" as stated by Władysław Wróblewski ${ }^{30}$. For obvious geographical reasons, this solution interfered with the Czechoslovak aspiration to become a neighbour of the Ukrainians or Russians.

The Kingdom of SCS played the least significant role from the Polish point of view, which was influenced by the geographical dis-

27 A. Kastory, Rozbiór Rumunii w 1940 roku, Warszawa 2002, pp. 10-24.

${ }^{28}$ In later years, the military staff officers considered the transit from Trieste to Poland via Banat and further Romania. Yet, it required major investments in the construction of the railway network as well as an appropriate bridge over the Danube.

${ }^{29}$ High Command of PA to Gen. T. Rozwadowski (head of the Polish Military Mission in Paris), Warsaw Apr 26, 1919, AAN, MSZ, file 236, sheet No. 9; W. Stępniak, op. cit., pp. 115-116, 250-251.

${ }^{30}$ Wróblewski to the Polish Legation in Sofia, Warsaw Feb 22, a of the MFA from May 12 and the Liquidation Commission of KNP to Paderewski, Paris Apr 22, 1919, PDD 1919: styczeń-maj, pp. 326, 625-627, 680-681. 
tance between the two countries. Still, Poland was well aware of all the weaknesses of this country: the hostility of neighbours who sought to capture the disputed territories (Italy, Albania, Hungary, Austria, Greece, Bulgaria, and even Romania in the case of Banat), as well as its internal inconsistency. There were national disputes between Serbs and other nationalities, mainly Croats, over the political and legal systems to be adopted - the first wanted centralism, while the others opted for federalism. Another major internal conflict was the issue of the Montenegrin royal family which received support from Rome. Nonetheless, the internal stability of the Kingdom of SCS was crucial for Polish plans to make Trieste a transit port for war materials to Poland in the case of war. The pro-Russian sympathies in Belgrade could also turn dangerous (a large colony of "white" emigrants was stationed in Serbia, though Warsaw did not consider it to be an anti-Polish movement). In addition, the South Slavs counted on German support, seeking their help in the fight against Italian territorial expansion and Berlin could exert pressure on Belgrade in any future confrontation with Poland to close the railway route from Triest. However, the first Polish-Yugoslavian diplomatic contacts were very cordial. When Czesław Pruszyński arrived in Belgrade to present his diplomatic credentials on January 6, 1919, Mihailo Gavrilović, who received a copy of this letter of credence, greeted the Polish chargé d'affaires with warm words. The head of the Serbian diplomacy expressed the will to establish "the closest possible relations between all the brotherly Slavic nations" ${ }^{1}$.

In conclusion, it should be stated that the Danube basin, in which the successor states were situated, was really important area to the nascent Poland. Therefore, Polish diplomats and military officers kept monitoring the situation in Central Europe, the traces of which are extant in the archives despite material damages incurred during World War II. The number of preserved sources from 1920 is definitely higher than from the two previous years. The records give

${ }^{31}$ Pruszyński to the MFA, Belgrade Jan 15, 1919, PDD 1919: styczen-maj, p. 72; reports of the military attaché in Belgrade from Sep 1, 1919 and May 30, June 6 and 22 as well as Jul 31, AAN, Amb. Londyn, file 66, sheet No. 2-4, 25, 30-32, 35-38, 42-43; reports for the High Command of PA from Jul 1 and 15, Sep 15, and Dec 1, AAN, MSZ, file 222, sheet No. 10-11, 25, 46, 64; report for the High Command of PA from Aug 1, 1920, ibidem, file 221, sheet No. 14; W. S tę pniak, op. cit., pp. 140-143, 147-149. 
a clear indication of how significant the successor states were to Poland. It should be noted, however, that despite strong interest, Polish diplomacy was not allowed to participate in the decisionmaking process about the fate of this region at the Paris Peace Conference, as it was the sole preserve of the Great Powers. Secondly, the region consisting of Czechoslovakia, Austria, Hungary, Romania and the Kingdom of SCS was not of primary importance to Warsaw compared to the Eastern and Western neighbours which were regarded to be far more significant because the independence, security and territorial integrity of Poland were seriously endangered by Germany and Russia. Therefore, a more intense political activity in the Danube Region was possible only after dealing with the threat from the East in the summer and autumn of 1920.

The Poles were politically engaged with the successor states of the Austro-Hungarian Empire as much as they possibly could. Firstly, they actively participated in negotiations regarding the distribution of state goods and assets that remained after the dissolution of the dual monarchy. Secondly, Warsaw looked for allies among the states that emerged out of the ruins of the Habsburg Monarchy. The most important outcome of this political activity was cooperation with Romania which culminated in the successful conclusion of the anti-Russian alliance of March 1921. All attempts to collaborate with Budapest against Czechoslovakia failed. Warsaw adopted a line of limited and uneasy cooperation with the Little Entente while keeping the best achievable relations with Hungary. At the beginning of the 1920s, in the face of immense instability in Europe, any activity that could be construed as being against the interest of Poland's close ally of France was unthinkable. This maintenance of closeness to France was not disrupted even to the point of tolerating Prague's hostile political and propaganda activities and attitudes towards Poland. Warsaw limited its counter-action to such hostility by creating greater difficulties and dissension in the ranks of the Little Entente.

Austria held a somewhat peculiar place in the Polish politics of 1918-1920. Its political and economic weakness was no mystery and thus, the Polish government accused Vienna of triggering the fights in Lviv and supporting the exiled government of the Western Ukrainian People's Republic. Due to Polish propaganda, the military conflict over Eastern Galicia was explained as a fight 
between the members of Entente with the Ukrainians who were supported by hostile Austria. However, this matter was not vigorously publicised in order to avoid the further weakening of the Austrian Republic, which was already on the verge of collapsing. Warsaw feared that Germany could annex Austria and by doing so, not only increase its own German potential but also, to some extent, make impossible a reconstruction of Austria-Hungary, which would surely be a stronger entity than the newly reviving Poland. Interestingly, the Polish military officers considered Vienna the main centre of intrigues on the European scale. This view was definitely exaggerated.

Lastly, let us reflect on the most important traffic artery of Central Europe - the Danube. The Great Powers and the countries situated on its banks were willing to internationalise it. Each of the entities with the exception of Poland intended to achieve the most favourable conditions of using the Danube for both commercial shipping and defensive purposes. Even though the representatives from Warsaw participated in the negotiations of the Danube Commissions they did not seek any special rights for themselves since the river flowed from the West to the East but was not navigable from the territory of France. Furthermore, the condition of the merchant navy on the Danube and the lack of specialists and materials for repairs were all rated as being quite poor ${ }^{32}$. Therefore to Polish strategic thinking the longitudinal railway lines connecting Poland with the ports of Brăila and Trieste proved far more important than the Danube navigation.

${ }^{32}$ Szembek to the MFA, Budapest Dec 26, AAN, Amb. Paryż, file 27, sheet No. 18-29; report for the High Command of PA, May 1, AAN, MSZ, file 222, sheet No. 7; report for the High Command of PA, Dec 15, 1920, ibidem, file 215, sheet No. 50-51. In one of the reports from Vienna it was stated the French wanted to build a channel connecting the Oder and the Vistula rivers with the Danube, which would make them a thoroughfare between Poland and the West; yet, reports of this type seem far too optimistic - see report from May 21, 1919, AAN, KNP, file 50, pp. 83-84. 


\section{Bibliography}

\section{Handwiting SOURCes}

The Central Archives of Modern Records in Warsaw (Archiwum Akt Nowych w Warszawie) [AAN]

The Polish Embassy in Berlin (Ambasada RP w Berlinie) [Amb. Berlin], files 26, 49.

The Polish Embassy in London (Ambasada RP w Londynie) [Amb. Londyn], files 5, 11, 41, 55, 66, 87.

The Polish Embassy in Paris (Ambasada RP w Paryżu) [Amb. Paryż], files 9, 11, 27, 36, 223.

The Defense Attaché Offices (Attachaty), AII/56.

The Polish Delegation to the Paris Peace Conference (Delegacja Polska na Konferencję Pokojową w Paryżu), file 45.

The Polish National Committee (Komitet Narodowy Polski) [KNP], files 50, 104.

The Ministry of Foreign Affairs (Ministerstwo Spraw Zagranicznych) [MSZ], files 215, 217, 221, 222, 224, 228, 236, 5439, 5442, 6896.

Polish Legation in Athens (Poselstwo RP w Atenach), file 415.

The National Archives, London, Foreign Office 371: 3896, 4373.

\section{Printed sources}

Archiwum Polityczne Ignacego Paderewskiego, vol. II, ed. W. Stankiewicz, Warszawa 1976; vol. V, ed. B. Janicka, Warszawa 2001; vol. VI, eds A.G. Dąbrowski et al., Warszawa 2007.

O niepodległa i granice. Komitet Narodowy Polski. Protokoły posiedzeń 1917-1919, eds M. Jabłonowski, D. Cisowska-Hydzik, Warszawa-Pułtusk 2007.

Polskie dokumenty dyplomatyczne 1918: listopad-grudzień, ed. S. Dębski, Warszawa 2008.

Polskie dokumenty dyplomatyczne 1919: styczeń-maj, ed. S. Dębski, Warszawa 2016.

Świtalski K., Diariusz 1919-1935, eds A. Garlicki, R. Świętek, Warszawa 1992.

Wandycz P., Erazm Piltz a koncepcja polityki środkowoeuropejskiej, [in:] Międzymorze. Polska i kraje Europy Środkowo-Wschodniej XIX-XX wiek. Studia ofiarowane Piotrowi Łossowskiemu w siedemdziesiąta rocznicę urodzin, eds A. Ajnenkiel, P. Łossowski, Warszawa 1995, pp. 215-225.

\section{Press}

“Czas” 1918. 


\section{Studies}

Bułhak H., Poczatki sojuszu polsko-rumuńskiego i przebieg rokowań o konwencję wojskowa w latach 1919-1921, "Dzieje Najnowsze" 1973, vol. V, issue 3, pp. 7-24.

Essen A., Polityka Czechosłowacji w Europie Środkowej w latach 1918-1932, Kraków 2006.

Essen A., Polska a Mała Ententa 1920-1934, Warszawa-Kraków 1992.

Fest W., Peace or Partition. The Hapsburg Monarchy and British Policy. 1914-1918, London 1978.

Jeziorny D., Austria kanclerza Karla Rennera (1918-1920) w raportach polskich dyplomatów $i$ wojskowych, [in:] Austria i relacje polsko-austriackie $w X X$ i XXI wieku. Polityka - kultura-gospodarka, eds A. Kisztelińska-Węgrzyńska, K.A. Kuczyński, Łódź, 2014, pp. 67-83.

Jeziorny D., German Austria - British Colony? An Episode of the British Policy towards Central Europe in 1919, [in:] The Role of Britain in the Modern World, eds K. Kujawińska-Courtney, R. Machnikowski, Łódź 1999, pp. 177-193.

Jeziorny D., Londyn a spuścizna po monarchii Habsburgów. Sprawa Austrii w koncepcjach i praktyce dyplomatycznej Wielkiej Brytanii (1918-1919), Torun 2002.

Jeziorny D., Międzynarodowe znaczenie Austrii w okresie rząów Karla Rennera w ocenach dyplomacji polskiej, "Przegląd Zachodni” 2014, vol. LXX, No. 2, pp. 139-158.

Jeziorny D., Raporty znad Wełtawy - narodziny Czechosłowacji widziane oczami Cecila Goslinga, [in:] Czechosłowacja w stosunkach międzynarodowych w pierwszej połowie XX w. Studia i szkice, ed. A.M. Brzeziński, Warszawa 2003, pp. 8-22.

Kamiński M.K., Konflikt polsko-czeski 1918-1921, Warszawa 2001.

Kastory A., Rozbiór Rumunii w 1940 roku, Warszawa 2002.

Lewandowski J., Królestwo Polskie wobec Austro-Wegier 1914-1918, WarszawaŁódź 1986.

Lewandowski K., Sprawa ukrainska $w$ polityce zagranicznej Czechosłowacji w latach 1918-1932, Wrocław 1974.

Łaptos J., Kształtowanie sie francuskiej koncepcji konfederacji naddunajskiej w latach 1918-1920, "Zeszyty Naukowe Uniwersytetu Jagiellońskiego. Prace Historyczne" 1991, issue 97, pp. 57-78.

Majewski P., "Niemcy Sudeccy" 1848-1948. Historia pewnego nacjonalizmu, Warszawa 2007.

Miller D.E., Forging Political Compromise: Antonin Švehla and the Czechoslovak Republican Party. 1918-1933, Pittsburgh 1999.

Nowinowski S.M., Konstatacje i nadzieje. Dyplomacja czechosłowacka wobec kwestii bezpieczeństwa zbiorowego w Europie (1918-1925), Torun 2005.

Nowinowski S.M., Polska w dyplomacji czechosłowackiej 1926-1932, Łódź 2013. 
Nowinowski S.M., Stosunki polsko-czechosłowackie u progu drugiej wojny światowej. Bilans otwarcia, [in:] Między przymusowa przyjaźnia a prawdziwa solidarnością. Czesi - Polacy - Słowacy 1938/39-1945-1989, part 1, eds P. Blažek, P. Jaworski, Ł. Kamiński, Warszawa 2007, pp. 12-17.

Pajewski J., Odbudowa państwa polskiego 1914-1918, Warszawa 1985.

Parafianowicz H., Czechosłowacja $w$ polityce Stanów Zjednoczonych $w$ latach 1918-1933, Białystok 1996.

Perman D., The Shaping of Czechoslovak State. Diplomatic History of the Boundaries of Czechoslovakia, 1914-1920, Leiden 1962.

Sierpowski S., Stosunki polsko-włoskie w latach 1918-1940, Warszawa 1975.

Spira T., The Sopron (Ödenburg) Plebiscite of December 1921 and the German Nationality Problem, [in:] War and Society in East Central Europe, Vol. VI. Essays on World War I: Total War and Peacemaking. A Case Study on Trianon, eds B.K. Király, P. Pastor, I. Sanders, New York 1982, pp. 321-341.

Stępniak W., Dyplomacja polska na Bałkanach (1918-1926), Warszawa 1998.

Stolper G., Deutsch-Österreich als Sozial- und Wirtschaftsproblem, Wien 1921.

Szklarska-Lohmannowa A., Polsko-czechosłowackie stosunki dyplomatyczne w latach 1918-1925, Wrocław 1967.

Świętek R., Lodowa ściana. Sekrety polityki Józefa Piłsudskiego, 1904-1918, Kraków 1998

Wandycz P., France and her Eastern Allies 1919-1925. French-Czechoslovak-Polish Relations from the Paris Peace Conference, Minneapolis 1962.

Weiss E. de, Dispute for Burgenland in 1919, "Journal of Central European Affairs" 1943, vol. III, No. 2, pp. 147-166.

DARIUSZ JEZIORNY

\title{
Państwa sukcesyjne Austro-Węgier w dyplomacji polskiej (1918-1920)
}

\begin{abstract}
A ustria, Węgry, Czechosłowacja, Rumunia i Królestwo SHS, a także Polska to państwa nazywane krajami sukcesyjnymi monarchii habsburskiej, ponieważ powstały na jej gruzach. Artykuł koncentruje się na znaczeniu tych środkowoeuropejskich państw w dyplomacji polskiej w latach 1918-1920, czyli w okresie decydujacym dla ich niepodległego bytu. Celem artykułu jest odpowiedź na pytanie o to, jak postępujacy rozpad Austro-Węgier w roku 1918 był postrzegany przez polskie elity polityczne. W następnej kolejności istotne jest pytanie, jakie było stanowisko rząu niepodległego państwa polskiego wobec państwowości tworzacych się po rozpadzie monarchii Habsburgów. Pod uwagę wzięte zostały wszystkie kraje, które w całości lub w znaczącej części zagarnęły tereny austro-węgierskie. Pośród nich wyjątkiem są Włochy. Rzym zaanektował również znaczące tereny habsbur-
\end{abstract}


skie nad Adriatykiem, ale już wcześniej był uznawany za jedna $z$ ważniejszych stolic europejskich i nowe nabytki jedynie zwiększyły jego potencjał. Istotne jest również zauważenie, czy omawiane państwa odgrywały jakąśs rolę w polskiej polityce zagranicznej, a jeśli tak, to jak znaczaca. Podobne pytanie dotyczy całego terytorium Europy naddunajskiej. Jego polityczna i ekonomiczna jedność została zerwana po I wojnie światowej, co mogła wykorzystać rodząca się Rzeczpospolita, majac do czynienia ze słabszymi od siebie potencjalnie partnerami.

Słowa kluczowe: dyplomacja polska, państwa sukcesyjne Austro-Węgier, obszar naddunajski. 